ORIENTAL JOURNAL OF CHEMISTRY

An International Open Access, Peer Reviewed Research Journal

www.orientjchem.org
ISSN: 0970-020 X

CODEN: OJCHEG

2020, Vol. 36, No.(6):

Pg. 1103-1106

Brief communication

\title{
Effect of pH on Size and Concentration of Silver Nanoparticles Synthesized using Ixora coccinea Linn. Leaf Extracts
}

\section{DARWIN F. REYES ${ }^{1 *}$, GIL FABIEN S. CABRERA ${ }^{2}$, SHEMMA MICA V. MATA ${ }^{2}$, JAZMIN PARIZ D. SAN PEDRO², JADD CHRISTIAN C. PALIOC ${ }^{2}$ and GERVIN S. TANDINGAN ${ }^{2}$}

\author{
${ }^{1}$ Chemistry and Environmental Science Department, College of Arts and Sciences, Nueva Ecija \\ University of Science and Technology, General Tinio St., Cabanatuan City, \\ Nueva Ecija 3100 Philippines. \\ 'Laboratory High School, Nueva Ecija University of Science and Technology, General Tinio St, \\ Cabanatuan City, Nueva Ecija 3100 Philippines. \\ *Corresponding author E-mail: darwin.chem@gmail.com \\ http://dx.doi.org/10.13005/ojc/360612
}

(Received: October 11, 2020; Accepted: November 12, 2020)

\begin{abstract}
The synthesis of silver nanoparticles via plant-mediated approach is an emerging area of research interest worldwide. The procedure is cost-effective and does not require the use of toxic chemicals and complicated reaction conditions. In the present investigation, silver nanoparticles were prepared using the leaf extracts of Ixora coccinea Linn., a common ornamental shrub in the Philippines, as the reducing agent. The effect of $\mathrm{pH}$ on the synthesis was investigated, and results showed that the quality of the synthesized silver nanoparticles changes in varying $\mathrm{pH}$ of the reducing agent.
\end{abstract}

Keywords: Green synthesis, Ixora coccinea Linn., pH, plant-mediated synthesis, Silver nanoparticles.

\section{INTRODUCTION}

Nanotechnology is a promising field nowadays due to its multiple applications in various industries ${ }^{1}$. Nanoparticles having the range of 1-100 $\mathrm{nm}$ have interesting properties as compare to their bulk counterpart. In particular, silver nanoparticles (AgNPs) have been receiving fascination from people since the Middle Ages due to its unique properties and applications ${ }^{2}$. AgNPs have distinct physical and chemical properties that make them of potential value in microelectronics and medical imaging industries to name a few ${ }^{3}$.
Different methods of AgNP synthesis have been developed. One of the methods is the biological synthesis that emerged as green alternatives because it is cost-effective and environment-friendly ${ }^{4}$. The biological synthesis involved the use of environmentally benign materials as reducing agents such as disaccharide ${ }^{5}$, plant extracts $^{6-8}$, fungus ${ }^{9}$ and bacteria ${ }^{10}$. Of the green methods the application of plant extracts emerged due to reasons that it eliminates the elaborate process of maintaining cell cultures and aseptic environments ${ }^{4}$.

This is an Open Access article licensed under a Creative Commons license: Attribution 4.0 International (CC- BY). Published by Oriental Scientific Publishing Company @ 2018

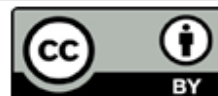


In the present study Ixora coccinea Leaf extracts were used for the synthesis of AgNPs. Ixora coccinea Linn., known as "santan" in the Philippines, is a low-growing tropical shrub with bright flowers composed of small blooms ${ }^{11-12}$. Reports on the traditional use of Ixora coccinea Linn. plant parts for the treatment of diverse ailments have been published ${ }^{11}$. Phytochemicals such as triterpenes, proanthocyanidins, and phenolic compounds have been reported to be present in Ixora coccinea Linn. ${ }^{13}$. These phytochemicals served as reducing agents for the synthesis of $\mathrm{AgNPs}^{6}$. The $\mathrm{pH}$ of Ixora coccinea Linn. leaf extracts were varied and the effect of variations in $\mathrm{pH}$ on the nanoparticle size and concentration was investigated.

\section{MATERIALS AND METHODS}

\section{Chemicals and equipment}

Ixora coccinea Linn. leaves were collected from Brgy. San Isidro, Cabanatuan City, Nueva Ecija, Philippines. Silver nitrate $\left(\mathrm{AgNO}_{3}\right)$ and sodium hydroxide $(\mathrm{NaOH})$ were used without any further purification. Distilled water was used as the solvent to prepare all the solutions used in this study. A Hitachi Double Beam Spectrophotometer UH 3500 was used for the AgNP characterization and estimation of size and concentration.

\section{Preparation of leaf extracts}

The healthy leaves of Ixora coccinea Linn. were washed with running tap water to remove the dirt and soil. The leaves were then rinsed with distilled water and chopped into small pieces. A $20 \mathrm{~g}$ of Ixora coccinea Linn. leaves and $100 \mathrm{~mL}$ of distilled water were allowed to boil with frequent stirring. The aqueous extracts were filtered and placed in an amber reagent bottle. The aqueous extracts were divided into two parts for $\mathrm{pH}$ adjustment. The $\mathrm{pH}$ of one part is $\mathrm{pH} 6$ and used as-is. While the $\mathrm{pH}$ of the other part was adjusted to $\mathrm{pH} 10$ using a dilute $\mathrm{NaOH}$ solution.

\section{Synthesis of AgNPs}

The green synthesis of AgNPs was adapted from the reported procedure14 with some modifications. In brief $5 \mathrm{~mL}$ of Ixora coccinea Linn. leaf extracts were added to $45 \mathrm{~mL}$ of $1 \mathrm{mM}$ $\mathrm{AgNO}_{3}$ solution. The reaction mixture was allowed to boil while vigorously stirred for 30 minutes. The completion of the reaction was signified by the change in the color of the reaction mixture. The synthesized AgNPs were transferred to an amber reagent bottle and stored at $4^{\circ} \mathrm{C}$ before characterization experiments.

\section{Characterization of green AgNPs}

The synthesized AgNPs were characterized using UV-Vis spectrophotometry (Hitachi Double Beam Spectrophotometer UH 3500). The synthesized AgNPs were diluted with distilled water and the absorbance values from 350-700 nm were obtained. The absorbance values were used to estimate the sizes, and concentrations of the synthesized AgNPs from a tabulated reference data-set ${ }^{15}$.

\section{RESULTS AND DISCUSSION}

The effects of $\mathrm{pH}$ on the synthesis of AgNPs were investigated by comparing the surface plasmon, size and concentration of the synthesized AgNPs. The $\mathrm{AgNO}_{3}$ precursor solution was colorless. Upon the completion of the reaction, the color of the solution turned to yellow to dark brown, indicating the formation of AgNPs due to the reduction of silver ions by phytochemicals present in the Ixora coccinea Linn. leaf extracts ${ }^{16}$. The differences on the color intensity of the synthesized AgNPs were observable Fig. 1 and can be attributed to the difference in the concentration of AgNPs in the sample. The $\mathrm{pH}$ of the Ixora coccinea Linn. leaf extracts affected the formation of nuclei for AgNPs synthesis resulting from increasing or decreasing number of $\mathrm{AgNPs}^{17}$.

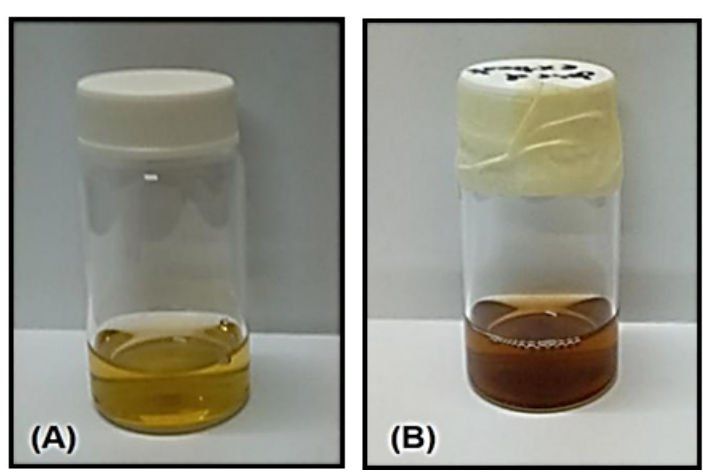

Fig. 1. The synthesized AgNPs using Ixora coccinea Linn. leaf extracts with (A) $\mathrm{pH} 6$ and (B) $\mathrm{pH} 10$

The spectral characteristics of the synthesized AgNPs are associated with its surface plasmon resonance (SPR) ${ }^{18}$ Fig. 2. SPR is due to mutual vibrations of the free conduction electrons in resonance with light, which is influenced by the size 
and shape of the synthesized nanoparticles ${ }^{19}$. The maximum absorption $\lambda_{\text {max }}$ peaks of the synthesized AgNPs at pH 6 and $\mathrm{pH} 10$ were $452 \mathrm{~nm}$ and 439 $\mathrm{nm}$, respectively. These values were within 320-580 $\mathrm{nm}$, which is characteristic $\lambda_{\max }$ for $\mathrm{AgNPs}^{20}$.

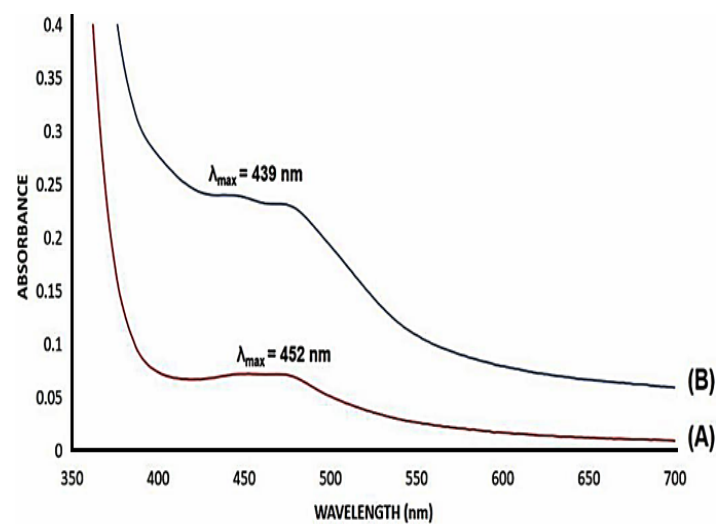

Fig. 2. UV-Vis spectra of synthesized AgNPs using Ixora coccinea leaf extracts with (A) pH 6 and (B) pH 10

The estimated concentrations of AgNPs at $\mathrm{pH} 6$ and 10 were $2.7 \times 10^{-3} \mathrm{nM}$ and $1.1 \times 10^{-2}$ nM, respectively Fig. 3. Thus, the results suggest that more AgNPs were obtained from the Ixora coccinea Linn. leaf extracts with a $\mathrm{pH}$ of 10 . These results are due to the possible ionization of functional groups of secondary metabolites at high $\mathrm{pH}$ present in the leaf extracts. It is reported that flavonoids such as catechins and cyanidins were isolated in the leaf extracts of Ixora coccinea Linn. ${ }^{21}$. It is probable that at high $\mathrm{pH}$, the hydroxyl groups $(-\mathrm{OH})$ of these flavonoids are deprotonated. Thus, these molecules served as the reducing and capping agents.

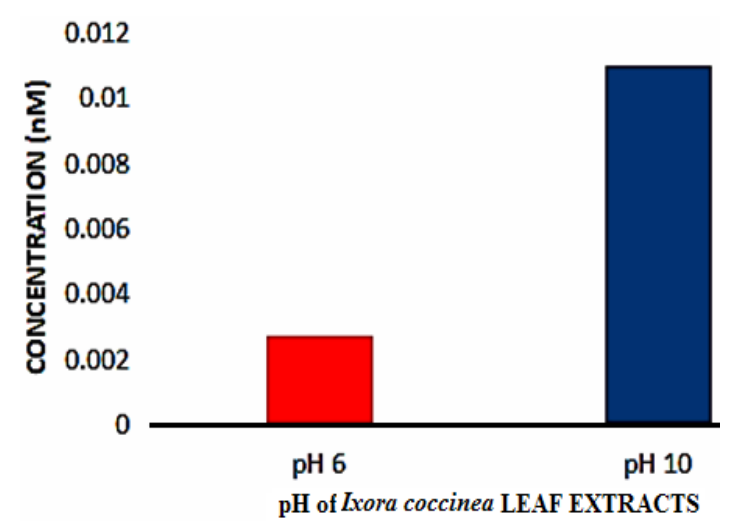

Fig. 3. Concentrations of synthesized AgNPs using Ixora coccinea Linn. leaf extracts with (A) pH 6 and (B) $\mathrm{pH} 10$
The sizes of the synthesized AgNPs using Ixora coccinea Linn. leaf extracts with varying $\mathrm{pH}$ were also estimated from a tabulated reference data-set ${ }^{15}$ Fig. 4. AgNPs synthesized at low pH are larger $(76 \mathrm{~nm})$ than the AgNPs synthesized at higher $\mathrm{pH}(66 \mathrm{~nm})$. This is attributed to the fact that the reaction rate at high $\mathrm{pH}$ is increased with subsequent crystallization into smaller particles. This crystallization involved the nucleation and growth processes of smaller particles from $\mathrm{Ag}$ nuclei22. Futhermore, $\mathrm{pH}$ values influence the size of green synthesized nanoparticles. This is due to the alteration of electrical charges of biomolecules and capping agents such as secondary metabolites due to ionization that results in changing their ability to bind and reduce metal ions ${ }^{20}$.

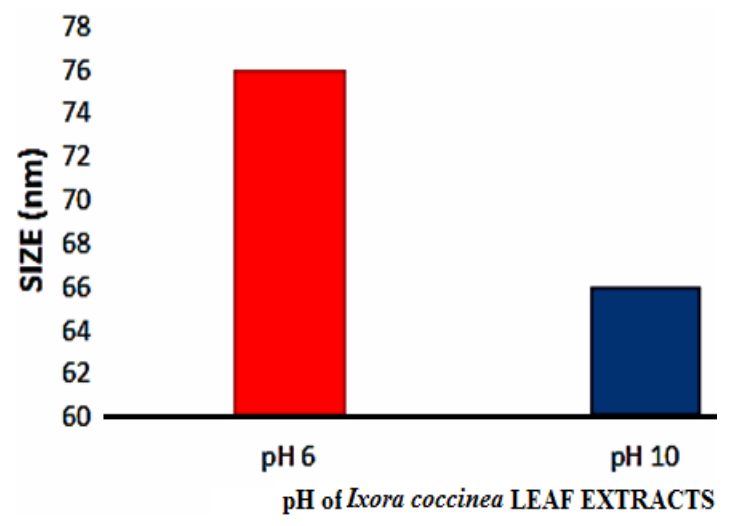

Fig. 4. Estimated sizes (in $\mathrm{nm}$ ) of synthesized AgNPs using Ixora coccinea Linn. leaf extracts with (A) $\mathrm{pH} 6$ and (B) pH 10

\section{CONCLUSION}

Herein, Ixora coccinea Linn. leaf extracts have been effectively used for the green approach of synthesizing AgNPs. This plant-mediated approach is cost-effective and straightforward. The $\mathrm{pH}$ of the Ixora coccinea Linn. leaf extracts were varied before using as a reducing agent in the synthesis. Results revealed that smaller and higher concentrations of AgNPs were obtained at alkaline leaf extracts. The effect of $\mathrm{pH}$ on the phytochemicals in the leaf extracts caused the observed variations in the quality of AgNPs. The study presented a simple and green approach to produce AgNPs for various applications in different fields.

\section{ACKNOWLEDGEMENT}

The authors would like to thank Mr. Gil Felicisimo S. Cabrera and the DARE TO (Discovery 
Applied Research and Extension for Trans/Interdisciplinary Opportunities) Cycle 2 Project funded by the Commission in Higher Education (CHED) for the UV-Vis spectrophotometric analysis and to the Nueva Ecija University of Science and
Technology for the financial support.

\section{Conflicts of Interest}

The author declares that there are no conflicts of interest related to this article.

\section{REFERENCES}

1. Murali A. S.; Pillai A.; Sreehari H.; Sarma S.; Ajith P.; Vinod B. S.; Anil A.; Chandran S. S. IOP Conf. Ser.: Mater. Sci. Eng., 2019. 577, 012096.

2. Ahmed R. H.; Mustafa D. E. Int. Nano. Lett., 2020, 10, 1-14.

3. Tran Q. H.; Nguyen V. Q.; Le A. T. Adv. Nat. Sci.-Nanosci., 2013, 4, Article ID: 033001.

4. Sinha S. N.; Paul D. Spectrosc. Lett., 2015. 48, 600-604.

5. Reyes DF. Orient. J. Chem., 2020, 36(4), 640644.

6. Hussain A.; Alajmi M. F.; Khan M. A.; Pervez S. A.; Ahmed F.; Amir S.; Husain F. M.; Khan M. S.; Shaik G. M.; Hassan I.; Khan R. A.; Rehman M. T. Front. Microbiol., 2019, $10,8$.

7. Wahab A. W.; Karim A.; Nafie N. L.; Nurafni; Sutapa I. W. Orient. J. Chem., 2018, 34(6), 3088-3094.

8. Chung I. M.; Park I.; Seung-Hyun K.; Thiruvengadam M.; Rajakumar G. Nanoscale Res. Lett., 2016, 11(1), 40.

9. Guilger M.; Pasquoto-Stigliani T.; Bilesky-Jose N.; Grillo R.; Abhilash P. C.; Fraceto L. F.; Lima R. Sci. Rep., 2017, 7, 44421.

10. Adan M. F.; Baybay Z. K.; Lantican N. B.; Fernando L.M.; Paterno E.S.; Villegas L. C.; Ilag L. L.; Montecillo A. D. Philipp. Sci. Lett., 2018, 11(2), 75-83.
11. Baliga M. S.; Kurian P. J. Chin. J. Integr. Med., 2012, 18(1), 72-79.

12. Karishma S. K.; Reddy D. R. B.; Manasa P.; Mariyamma P.; Jyothi S.; Asma S. K. World J. Pharm. Res., 2019, 8(3), 1292-1298.

13. Martins D.; Nunez C. V. Molecules., 2015. 20(7), $13422-13495$.

14. Vinay S. P.; Chandrasekhar N.; Udayabhanu; Nagarju G.; Chandrappa C. P. Int. J. Biosens. Bioelectron., 2019, 5(4), 100-105.

15. Paramelle D.; Sadovoy A.; Gorelik S.; Free P.; Hobleya J.; Fernigb D. G. Analyst., 2014, 139, 4855.

16. Kredy HM. (2018). Int. J. Pharm. Sci. Res., 2018, 10(8), 2022-2026.

17. Traiwatcharanon P.;Timsorn K.; Wongchoosuk C. Adv. Mat. Res., 2015. 1131, 223-226.

18. Buccolieri A.; Serra A.; Giancane G.; Manno D. Beilstein J. Nanotechnol., 2018, 9, 499-507.

19. Shrivas K.; Nirmalkara N.; Thakura S. S.; Deb M. K.; Shinde S. S.; Shankar R. Food. Chem., 2018, 250, 14-21.

20. Hamouda R. A.; Hussein M. H.; Abo-elmagd R. A.; Bawazir S. S. Sci. Rep., 2019, 9, 13071.

21. Baliga M. S.; Kurian P. J. Chin. J. Integr. Med., 2011, 17(10), 1-9.

22. Anigol L. B.; Charantimath J. S.; Gurubasavaraj P. M. Org. Med. Chem. Intl. J., 2017, 3(5), 555622. 